\title{
Hydrolase-treated royal jelly attenuates LPS-induced inflammation and IgE-antigen-mediated allergic reaction
}

\begin{abstract}
Worrapanit Chansuwan $^{1 *}$, Matthawan Khamhae ${ }^{2}$, Zhe Yang ${ }^{3}$, Nualpun Sirinupong1
${ }^{1}$ Interdisciplinary Graduate School of Nutraceutical and Functional Food, Prince of Songkla University, Hat Yai, Songkhla 90110, Thailand; ${ }^{2}$ Functional Food and Nutrition Program, Faculty of Agro-Industry, Prince of Songkla University, Hat Yai, Songkhla 90110, Thailand; ${ }^{3}$ Department of Biochemistry, Microbiology, and Immunology, School of Medicine, Wayne State University, Detroit, Michigan 48201, USA
\end{abstract}

Corresponding Author: Worrapanit Chansuwan, PhD, Interdisciplinary Graduate School of Nutraceutical and Functional Food, $9^{\text {th }}$ Floor Learning Resources Center (Square building), Prince of Songkla University, Hat Yai, Songkhla 90110, Thailand

Submission Date: February $4^{\text {th }}$, 2020; Acceptance Date: March 26 ${ }^{\text {th }}$, 2020; Publication Date: March $30^{\text {th }}, 2020$

Citation: Chansuwan W., Matthawan KhamhaeM., Zhe Yang Z., Sirinupong N. Hydrolase treated royal jelly attenuates LPS-induced inflammation and IgE-antigen-mediated allergic reaction. Functional Foods in Health and Disease. 2020; 10(3): 127-142. DOI: https:/doi.org/10.31989/ffhd.v10i3.694

\begin{abstract}
Background: Royal jelly (RJ) is one of the most effectual and beneficial remedies for human beings and currently utilized in many sectors, ranging from the pharmaceutical and food industries to cosmetic and manufacturing sectors due to RJ possessing many bio-therapeutical activities including anti-tumor, antimicrobial and antioxidant activities, vasodilative and hypotensive activities, as well as growth-stimulating, infection-preventing, anti-hypercholesterolemic and antiinflammatory activities. However, some reports showing direct consumption of RJ can lead to severe allergic reaction and has been linked with acute asthma, dermatitis, and life-threatening anaphylaxis. Thus, this research purposes to explore the potential anti-inflammatory and antiallergic activities of hydrolyzed RJ as a function of enzyme and the extent of hydrolysis.
\end{abstract}

Methods: RJ was enzymatically hydrolyzed with three commercial enzymes (Alcalase ${ }^{\circledR}$, Flavourzyme ${ }^{\circledR}$ and Protamex $\left.{ }^{\circledR}\right)$. Anti-inflammatory activity of the hydrolysates was measured by their inhibitory effect on nitric oxide (NO) production of lipopolysaccharide (LPS)-stimulated RAW264.7 macrophage cells. Anti-allergy was determined from the ability of the hydrolysates to inhibit $\beta$-hexsosaminidase $(\beta$-HEX) release from RBL-2H3 mast cells. Cytotoxicity was also investigated in both RAW264.7 macrophage cells and RBL-2H3 mast cells. 
Results: The electrophoretic profiles indicated that Alcalase ${ }^{\circledR}$ and Flavourzyme ${ }^{\circledR}$ hydrolysates did not show the presence of proteins causing allergic reaction after 60 mins of hydrolysis while these allergens disappeared from Protamex ${ }^{\circledR}$ hydrolysate at the hydrolysis time of $240 \mathrm{~min}$. It was observed that hydrolyzed RJ showed no toxicity on RAW264.7 and RBL-2H3 cells. With the progression of hydrolysis, $\mathrm{IC}_{50}$ values of $\mathrm{NO}$ production inhibition significantly decreased while degree of hydrolysis (DH) was increased in all hydrolyzed samples ( $\mathrm{p}<0.05)$. Results of $\beta$-HEX release inhibition were found in the same fashion. Flavourzyme ${ }^{\circledR}$ hydrolysate at the $240 \mathrm{~min}$ time point effectively mitigated the oxidative stress and protected DNA in a dose dependent manner.

Conclusions: RJ hydrolysates from Flavourzyme ${ }^{\circledR}$ resulted in peptides with anti-inflammatory activity as determined by the inhibition of NO production in LPS-stimulated RAW264.7 macrophage cells and anti-allergic property as measured by the suppression of degranulation of sensitized RBL-2H3 cells. Anti-inflammatory effect may be due to their anti-oxidative capability. Inhibition of $\beta$-HEX release may be due to their membrane-stabilizing effects or/and blockade of IgE antibody binding to its receptors.

Keywords: anti-inflammation, enzymatic hydrolysate, royal jelly, anti-allergy

\section{INTRODUCTION}

Recently, the popularity of functional foods is increasing because of rising health-conscious consumers. The market for functional foods is increasing at an annual rate of 15-20\% [1]. Functional foods offer new options for people in prevention and treatment of health concerns because they are defined as foods or dietary components with health-enhancing properties beyond basic nutrition [2]. Among foods that possess potential health benefits, royal jelly (RJ) is one of the most attractive natural products, which is originated from beehives. RJ is a thick, whiteyellowish, creamy substance secreted from the hypopharyngeal and mandibular glands of young worker bees (Apis mellifera) for nutrition of all bee larvae and queen bees. Bee larvae consume RJ during their first 3 days of their life while queen bees continue to consume RJ for their whole life period [3, 4]. It is suggested that $\mathrm{RJ}$ is a potent promoter of healthy aging and longevity because it enhances overall health and fertility of queen bees, who may lay up to 3000 eggs a day and survive as long as five years compared with infertile workers that live up to 45 days only [4-6]. The scientific evidence has found that RJ has many bio-therapeutical activities including anti-tumor, antimicrobial and antioxidant activities, vasodilative and hypotensive activities, as well as growthstimulating, infection-preventing, anti-hypercholesterolemic and anti-inflammatory activities [7$10,51]$. This is the reason that $\mathrm{RJ}$ is one of the most effectual and beneficial remedies for human beings and currently utilized in many sectors, ranging from the pharmaceutical and food industries to cosmetic and manufacturing sectors [11].

The search for new anti-inflammatory and anti-allergic agents from a huge array of natural resources is intensifying [12]. Inflammation is a complex process involving the activation and deactivation of immune cells. As a defense mechanism, inflammation is vital to health. However, dysregulation of inflammation could result in cellular and tissue damage causing chronic diseases such as diabetes, Alzheimer's disease, atherosclerosis, septic shock, and cancer [13-15]. Studies of the mechanisms that underlie the inflammatory processes have increased considerably in recent decades. It is now well known that the inflammatory processes are associated with activation of 
various immune-system cells and numerous inflammatory mediators [16]. Macrophages are one of the key immune cells involved in initiating and maintaining the inflammatory response. Nitric oxide (NO) has been definitively recognized as one of the key inflammatory mediators involved in immunity and inflammation. NO is derived from the oxidation of L-arginine catalyzed by inducible NO synthase (iNOS) [17]. In parallel, the allergic process has an important inflammatory component in which mast cell activation and degranulation are the first phenomena observed. During this process, mast cells release several inflammatory mediators including histamine (5HT), platelet aggregating factor (PAF), leukotrienes, and a variety of cytokines [18]. In type I hypersensitivity allergic reaction, the release of these inflammatory mediators is IgE mediated [19]. In addition, $\beta$-hexosaminidase $(\beta$-HEX) is also stored in the secretory granules of mast cells and released along with histamine when mast cells are activated. Therefore, this enzyme is commonly used as a marker for mast cell degranulation and detection of anti-allergic activity.

There are several reports showing that direct consumption of royal jelly can lead to severe allergic reaction and has been linked with acute asthma, dermatitis, and life-threatening anaphylaxis [20-22]. RJ contains a family of proteins called major royal jelly proteins (MRJs), which have been identified as allergens [52]. However, another study reported two different proteins with the molecular weight of $47 \mathrm{kDa}$ and $55 \mathrm{kDa}$ as major allergens $[23,53]$. Nonetheless, many studies have been conducted to solve allergic problems caused by RJ consumption [24-25]. Hydrolyzed proteins have been suggested to be used to manage adverse food allergic reaction in human and pets [26]. This relies on the assumption that enzymatic treatment can modify the structure of allergens or redistribute the composition by creating a wide range of peptides with a small size so that they are not recognized as antigen, therefore, rendering non- or hypo-allergic properties [26]. Indeed, a variety of food protein hydrolysates have been shown to modulate the inflammatory response with anti-inflammatory and anti-allergic activities [27]. In this study, the anti-inflammatory and anti-allergic effects of RJ-derived proteins and their enzymatic hydrolysates were investigated as a function of enzyme and the extent of hydrolysis in mammalian cell lines.

\section{MATERIALS AND METHOD}

\section{Materials}

Three batches of pure fresh royal jelly (RJ) from the honeybee species Apis mellifera were acquired directly from beekeepers. The farms were located in Northern Thailand. RJ was transferred by a refrigerated truck and then kept in frozen $\left(-20^{\circ} \mathrm{C}\right)$. The storage period of samples used in this study was not more than six months.

\section{Chemical and Reagents}

Alcalase $^{\circledR} 2.4 \mathrm{~L}$ (2.4 AU/kg; density, $\left.1.18 \mathrm{~g} / \mathrm{ml}\right)$, an endoproteinase from Bacillus licheniformis, Flavourzyme $^{\circledR}(1000 \mathrm{LAPU} / \mathrm{kg}$; density, $1.27 \mathrm{~g} / \mathrm{ml})$, an exoproteinase from Aspergillus oryzae, and Protamex ${ }^{\circledR}$, a mixture of endo- and exo-peptidases from Bacillus sp. were obtained from Sigma-Aldrich (St. Louis, MO, USA). Minimum essential medium eagle (MEM), anti-DNP IgE (Monoclonal Anti-DNP), lipopolysaccharide (LPS, Escherichia coli), RPMI-1640 medium, 3(4,5-dimethyl-2-thiazolyl)-2,5-diphenyl-2H-tetrazolium bromide (MTT), and 1-nitroarginine (1NA) were purchased from Sigma. Fetal calf serum (FCS) was from Gibco. All chemicals used in the experiments were of analytical grade. 


\section{Cell culture}

Anti-inflammatory activity was determined by the inhibitory ability of RJ hydrolysates against NO production in LPS-stimulated murine RAW264.7 macrophage cells. Anti-allergic activity was determined by the inhibitory ability of RJ hydrolysates against $\beta$-hexosaminidase ( $\beta$-HEX) secretion using the rat mast cell line RBL-2H3. Both cell lines were purchased from American Type Culture Collection (ATCC). The RAW264.7 cells were cultured in RPMI-1640 medium supplemented with $0.1 \%$ sodium bicarbonate and $2 \mathrm{mM}$ glutamine, penicillin $\mathrm{G}$ (100 units/ml), streptomycin $(100 \mu \mathrm{g} / \mathrm{ml})$, and 10\% FCS. The RBL-2H3 cells were cultured in MEM containing penicillin (100 units/ml), streptomycin (100 units/ml), and 15\% FCS. The cells were incubated at $37^{\circ} \mathrm{C}$ in $5 \% \mathrm{CO}_{2}$ /air.

\section{Royal jelly hydrolysate Preparation}

Royal jelly was hydrolyzed by three different enzymes: Alcalase ${ }^{\circledR}$, Flavourzyme ${ }^{\circledR}$, and Protamax ${ }^{\circledR}$. The optimum conditions used for hydrolysis were based on the recommended conditions from the supplier. The RJ samples were mixed with deionized water at a ratio of 1:2. The reaction was performed in a closed glass vessel with a double jacket and constant agitation at $200 \mathrm{rpm}$ until the temperature reached to the optimum hydrolysis temperature. Then, the protease was added at a level of $1.0 \%(\mathrm{w} / \mathrm{w})$. Temperature was stabilized with a continuous flow water bath. The hydrolysis was carried out for six hours. Aliquots were taken at 0,60, 120, 180, 240, 300 and $360 \mathrm{~min}$. The reaction was terminated by heating at $85^{\circ} \mathrm{C}$ for $15 \mathrm{mins}$ before cooling on ice. The hydrolysate was then centrifuged at $10,000 \mathrm{x}$ g at $4^{\circ} \mathrm{C}$ for 15 mins. The soluble fraction was collected and kept at $20^{\circ} \mathrm{C}$ for further analysis.

\section{Determination of total protein content}

Protein content was measured according to the Lowry method [28] using bovine serum albumin (BSA) as a standard.

\section{Degree of hydrolysis analysis}

Degree of hydrolysis (DH) is defined as the ratio between the number of peptide bonds cleaved during hydrolysis reaction and total peptide bonds in raw material. DH of royal jelly hydrolysates was determined by measuring the amount of free amino acids according to the reaction with Trinitobenzene sulfonic acid (TNBS) [29]. The absorbance was read at $420 \mathrm{~nm}$ and $\alpha$-amino group was expressed in terms of L-leucine.

\section{SDS-PAGE and Coomassie blue staining}

Hydrolyzed samples from different treatments were analyzed by SDS-PAGE [30] using a Bio-Rad Mini-Protean Tetra Cell system (Bio-Rad, Hercules, CA, USA) in the buffer and gel system proposed by Schagger and Jagow [31]. The separation was carried out using 4\% stacking and 16\% resolving gels at a voltage of $50 \mathrm{~V}$. The samples $(2 \mathrm{mg} / \mathrm{mL})$ were heated in the reducing buffer (62.5 mM Tris-HCl, pH 6.8, 2.0\% (w/v) SDS, 0.002\% (w/v) bromophenol blue, 5\% (v/v) $\beta$ mercaptoethanol, and $10 \%(\mathrm{v} / \mathrm{v})$ glycerol) at $100^{\circ} \mathrm{C}$ for 5 mins prior to analysis. A total of $0.2 \mu \mathrm{g}$ of the sample was loaded per well. Protein bands were stained with Coomassie Brilliant Blue R250 . 


\section{Cell viability assay}

A cell viability assay was performed with both RAW264.7 and RBL-2H3 cells using the MTT colorimetric method according to previously described [26]. Briefly, after $48 \mathrm{~h}$ incubation with the test samples, MTT solution $(10 \mu \mathrm{l}, 5 \mathrm{mg} / \mathrm{ml}$ in PBS $)$ was added to the wells. After $4 \mathrm{~h}$ incubation, the medium was removed and DMSO was then added to dissolve the formazan production in the cells. The optical density of the formazan solution was measured with a microplate reader at 570 $\mathrm{nm}$. The test samples were considered cytotoxic when the optical density of the sample-treated group was less than $80 \%$ of that in the control (vehicle-treated) group [19].

\section{DNA damage protection assay}

The ability of RJ hydrolysates to protect DNA from Fenton's reagent-induced damage was assessed by DNA damage protection assay with slight modifications [32]. Genomic DNA was isolated from HEK-293 cells. The reaction mixture was made by mixing $0.2 \mu \mathrm{g}$ of DNA, $3 \mu \mathrm{L}$ of

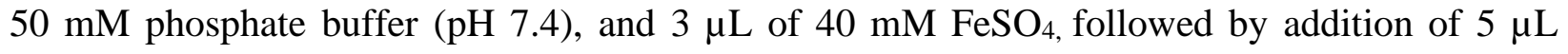
samples $(0.5,1.0,2.0$ or $5.0 \mathrm{mg} / \mathrm{ml})$ and $4 \mu \mathrm{L}$ of $1 \mathrm{mM} \mathrm{H}_{2} \mathrm{O}_{2}$. The reaction mixture was then incubated for $30 \mathrm{mins}$ at $37^{\circ} \mathrm{C}$. After that, $5 \mu \mathrm{L}$ of $1 \mathrm{mmole} / \mathrm{L}$ gallic acid was added immediately to terminate the reaction. Finally, the DNA was visualized with $1 \%$ agarose gel electrophoresis.

\section{Determination of anti-inflammatory activity}

Anti-inflammatory activity of samples was evaluated based upon their inhibitory effect on nitric oxide (NO) production in murine RAW264.7 macrophage cells according to the procedure described earlier [26]. The 1-NA (NO synthase inhibitor) was used as positive control. The stock solution of each test sample was dissolved in deionized distilled water. Inhibition (\%) was calculated using the following equation and $\mathrm{IC}_{50}$ values were determined graphically $(n=4)$ :

$$
\text { Inhibition }(\%)=\frac{(\mathrm{A}-\mathrm{B}) \times 100}{(\mathrm{~A}-\mathrm{C})}
$$

where A is NO concentration $(\mu \mathrm{g} / \mathrm{ml})$ with LPS and without sample; B, with LPS and sample; C, without LPS and sample.

\section{Determination of anti-allergic activity}

The anti-allergic activity of samples was evaluated based upon their inhibitory effect on the release of $\beta$-HEX from RBL-2H3 cells according to the method described by Chansuwan and Chinachoti [26]. The test samples were dissolved in deionized distills water, and the solutions were added to Siraganian buffer. Inhibition (\%) of the release of $\beta$-HEX by the test sample was calculated using the following equation and $\mathrm{IC}_{50}$ values were determined graphically $(n=4)$ :

$$
\text { Inhibition }(\%)=\left(\frac{1-(\mathrm{T}-\mathrm{B}-\mathrm{N})}{\mathrm{C}-\mathrm{N}}\right) \times 100
$$

where $\mathrm{C}$ is control with DNP-BSA and without sample; T, test with DNP-BSA and sample; $\mathrm{B}$, blank without DNP-BSA and sample; N, normal without DNP-BSA and sample. 


\section{Statistical Analysis}

Data were subjected to Analysis of Variance (ANOVA) and Duncan's Multiple Range Test. The SPSS statistics program (Version 16.0) was used for data analysis. Statistical significance was tested at $p<0.05$.

\section{RESULTS AND DISCUSSION}

\section{Degree of hydrolysis (DH)}

$\mathrm{DH}$ is an indicator of hydrolysis progress which reflects the ability of proteases to access available cutting sites of protein. DH is defined as the proportion of peptides bond cleaved during proteolysis to the total peptide bond available in the protein structure. The results revealed that Alcalase ${ }^{\mathbb{R}}$ hydrolysates had the highest DH of $33.6 \%$, followed by Flavourzyme ${ }^{\circledR}$ hydrolysates $27.4 \%$ and Protamex ${ }^{\circledR} 18.3 \%$ after 6 hours of hydrolysis (Figure 1). Protamex ${ }^{\circledR}$ hydrolysates showed significantly the lowest DH with $\mathrm{p}<0.05$. All proteolysis curves showed that royal jelly was degradable by all three proteases, and the differences between their DH values implied that the number of available cutting sites for Alcalase ${ }^{\circledR}$ was the largest. Additionally, the results also showed the DH values increased with the hydrolysis time, which was in agreement with the results of other protein hydrolysates previously reported [26, 33].

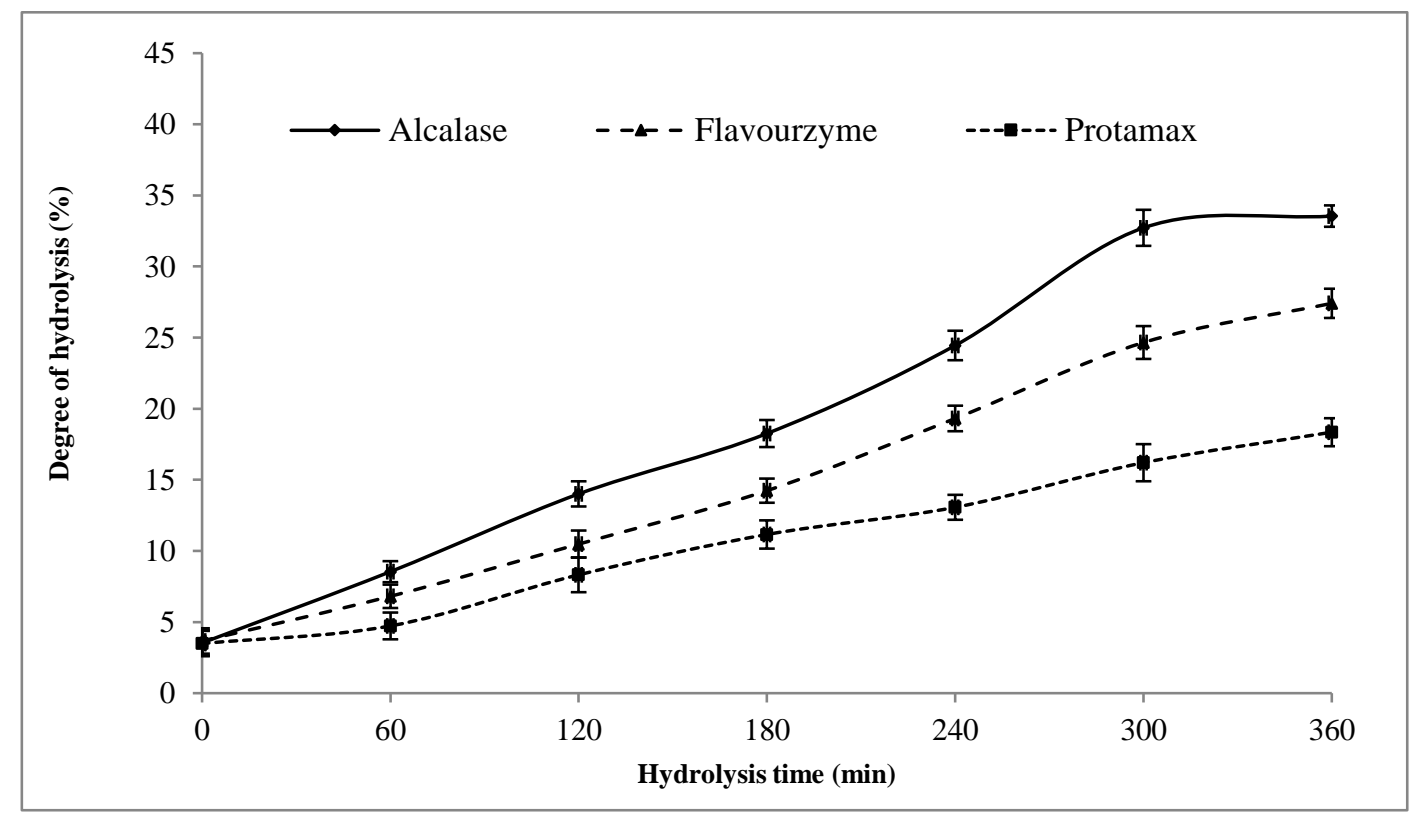

Figure 1. Relationships between hydrolysis time and DH of three proteases.

\section{Molecular weight distribution of hydrolysis-derived peptides}

Gel electrophoresis was employed to observe the size distribution of the hydrolyzed proteins and estimate their molecular masses. The electrophoretic patterns of RJ hydrolyzed by Alcalase ${ }^{\circledR}$, Flavourzyme ${ }^{\circledR}$, and Protamex ${ }^{\circledR}$ are shown in Figure 2. The resulting hydrolysates comprised a mixture of peptides of different lengths. Alcalase ${ }^{\circledR}$ rapidly cleaved RJ into peptides, while Protamex ${ }^{\circledR}$ showed the slowest hydrolysis rate (Figure $\left.2 A\right)$. Flavourzyme ${ }^{\circledR}$ hydrolysis resulted in relatively larger fragments that were stable over the entire hydrolysis (Figure 2B). However, Alcalase ${ }^{\circledR}$ hydrolysis resulted in very small fragments even only after 60 mins of cleavage. Protamex ${ }^{\circledR}$ showed the least amount of cleavage with larger fragments (Figure 2C). 
Alcalase ${ }^{\circledR}$ is an endopeptidase that has a limited range of peptide-bond specificities for hydrolysis. On the other hand, Flavourzyme ${ }^{\circledR}$ and Protamex ${ }^{\circledR}$ are mixtures of endopeptidases and exopeptidases, giving them a broader range of actions; thus, a higher $\mathrm{DH}$ is expected when compared with hydrolysis by Alcalase ${ }^{\circledR}$ [34]. However, the limited hydrolysis (lower DH) and presence of both high and low molecular weight bands in the electrophoretic profiles (Figure 1 and 2) could indicate that the effectiveness of Flavourzyme ${ }^{\circledR}$ and Protamex $\AA$ towards RJ proteins was largely limited to their exopeptidase activity [35]. Nonetheless, treatment with Alcalase ${ }^{\circledR}$, Flavourzyme ${ }^{\circledR}$, or Protamex ${ }^{\circledR}$ all resulted in the prominent change in the SDS-PAGE profiles (Figure 2), showing the extensive hydrolysis of two RJ allergens (MW: 47 and $55 \mathrm{kDa}$ ) [23]. Alcalase ${ }^{\circledR}$ and Flavourzyme ${ }^{\circledR}$ hydrolysates showed the disappearance of these two allergens after 60 mins of hydrolysis, while they were absent from Protamex ${ }^{\circledR}$ hydrolysate at the hydrolysis time of 240 min (Figure 2). Thus, this finding indicated that these allergy-causing proteins could be efficiently removed by proteolytic treatment, therefore rendering non- or hypo-allergic properties.
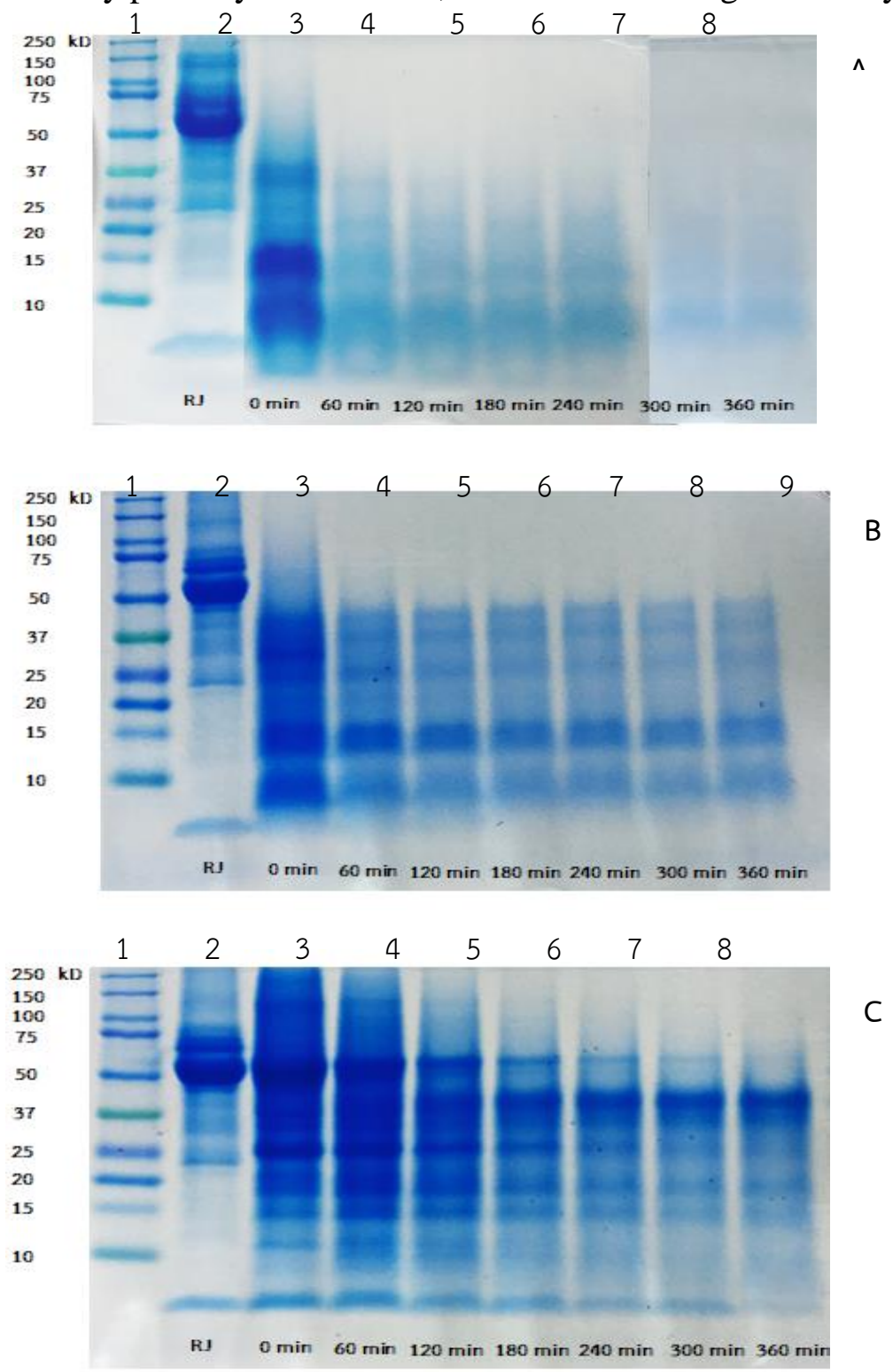

Figure 2 SDS-PAGE electrophoretic profiles of time-course RJ hydrolysis by (A) Alcalase ${ }^{\circledR}$, (B) Flavourzyme $\AA$, and $(C)$ Protamex ${ }^{\circledR}$ 


\section{Anti-inflammatory activity}

Macrophages are activated in response to invading microorganisms and foreign antigens to produce NO [36]. However, excessive production of NO by activated macrophages can cause oxidative stress and inflammation leading to general tissue damage and DNA mutation [26]. Therefore, tight regulation of NO production is essential to the immune system. Prior to evaluation of their inhibitory effect on NO production, we first used MTT assay to investigate the effect of RJ hydrolysates on macrophage cell viability. Various concentrations of hydrolyzed RJ (0-10 mg protein $/ \mathrm{ml}$ ) were tested, and the results indicated that the cell viability of all hydrolysate-treated macrophages was over $80 \%$ compared to the control [26] implying that these hydrolyzed samples had no cytotoxicity (data not shown). Therefore, the concentrations of 0-10 mg protein/ml RJ and its hydrolysates were used throughout the study to assess their potential anti-inflammatory activity in RAW264.7 macrophage cells.

Investigating the inhibition of NO production in macrophages is fundamentally important because targeting LPS-induced NO production may stand a good chance of effectively preventing inflammatory reactions and diseases [37]. Enzymatic hydrolysates of RJ were prepared and their NO production inhibitory activity was investigated in LPS-stimulated RAW264.7 cells. The cells were treated with different concentrations of hydrolyzed RJ samples followed by LPS stimulation. After $24 \mathrm{~h}$ incubation, NO production in the culture medium was quantified using Griess reagent. The results showed that the half maximal inhibitory concentrations $\left(\mathrm{IC}_{50}\right)$ significantly decreased in all hydrolysate treatments, which were correlated with the increased DHs and progression of hydrolysis $\left(\mathrm{p}<0.05\right.$ ) (Figure 3 ). Their $\mathrm{IC}_{50}$ values decreased by about 4 -folds compared to the non-hydrolyzed controls after 60 mins of hydrolysis and by about 8 -folds to the asymptotic level at $360 \mathrm{~min}$ of hydrolysis. This result suggested that the small sizes of peptides exhibited stronger anti-inflammatory activity than larger peptides. The higher DH might have rendered a larger portion of low MW peptides, allowing for more effective penetration into the lipid bilayer of cells. This result was in accordance with previous studies indicating that the smaller sizes of peptides derived from food proteins such as salmon [38], soybean [39], egg [40], and whey [41] possessed a stronger NO inhibitory activity than higher ones in LPS-stimulated RAW264.7 macrophages. Additionally, hydrolyzed RJ was previously shown to possess anti-inflammatory activity through reduction of pro-inflammatory cytokines such as TNF- $\alpha$, IL-1, IL-6, IL-10, IL-12, and IFN- $\gamma$ in mice [42].

Other factors, such as the peptide sequences and amino acid compositions can also determine the bioactivity of protein hydrolysates. It has been shown that electron donation by the sulfhydryl group of cysteines leading to dimerization of hydrolyzed peptides contributed to the antiinflammatory activity, although this mechanism would be more relevant in free radical quenching than ROS scavenging [43]. Thus, the structure-function relationships of anti-oxidative and antiinflammatory peptides and protein hydrolysates appear to be very complex, especially within the physiological matrices. The lowest $\mathrm{IC}_{50}$ value observed for Flavouzyme ${ }^{\circledR}$ hydrolysate was $0.15 \pm 0.03 \mathrm{mg}$-protein $/ \mathrm{ml}$ at $240 \mathrm{~min}$ of hydrolysis (Figure 2B). However, this $\mathrm{IC}_{50}$ value was higher than L-nitroarginine $(20.44 \pm 1.84 \mu \mathrm{g} / \mathrm{ml})$, which is known to be the most specific NO synthase inhibitor. 

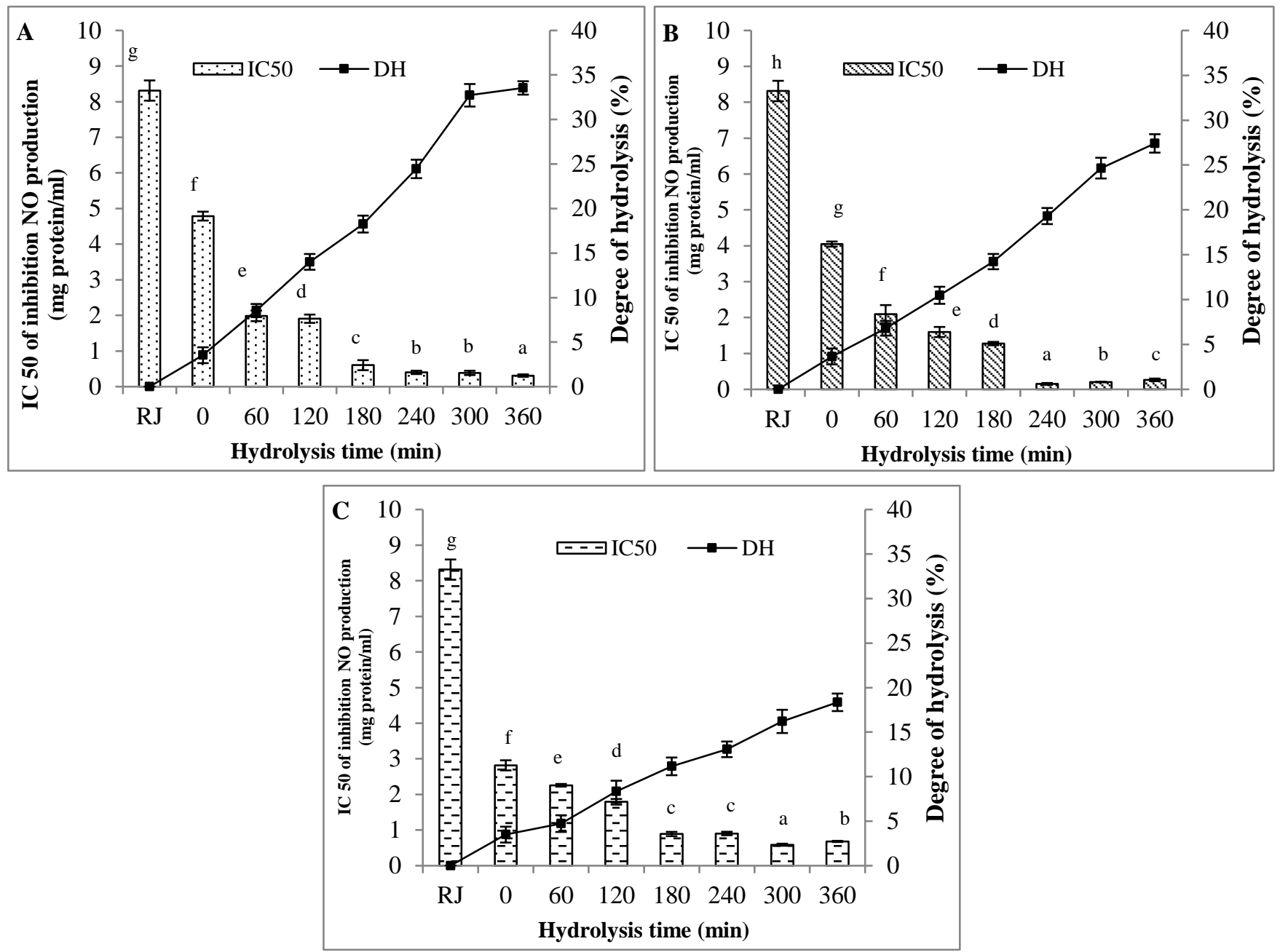

Figure 3 Hydrolysis-time dependent inhibitory analysis of NO production using hydrolyzed RJ. (A) Alcalase ${ }^{\circledR}$, (B) Flavourzyme ${ }^{\circledR}$, and (C) Protamex ${ }^{\circledR}$. $\mathrm{IC}_{50}$ was overlaid with degree of hydrolysis $(\mathrm{DH})$. Letters depicted statistically significant differences at $\mathrm{p}<0.05$.

\section{DNA damage protecting activity}

The excessive production of reactive oxygen species (ROS) can cause a variety of degenerative disorders such as cancer, premature aging, cardiovascular disease, and neurodegenerative disease. DNA damage is a key step in these ROS-induced disorders [44]. To examine whether RJ hydrolysates have a DNA protective activity, DNA damage to a model genomic DNA from HEK293 cells was induced by the Fenton's reaction in the presence of Flavourzyme ${ }^{\circledR}$ hydrolysates. The hydroxyl radicals generated by the Fenton's reaction are known to cause oxidative DNA damage. After incubation with the Fenton's reagent, the genomic DNA band was disappearing and a smear of degraded DNAs was observed. The RJ hydrolysates effectively mitigated the oxidative stress and protected DNA in a dose dependent manner, as evidenced by the increasing intensity of genomic DNA bands (Figure 4, lane 3-6). 


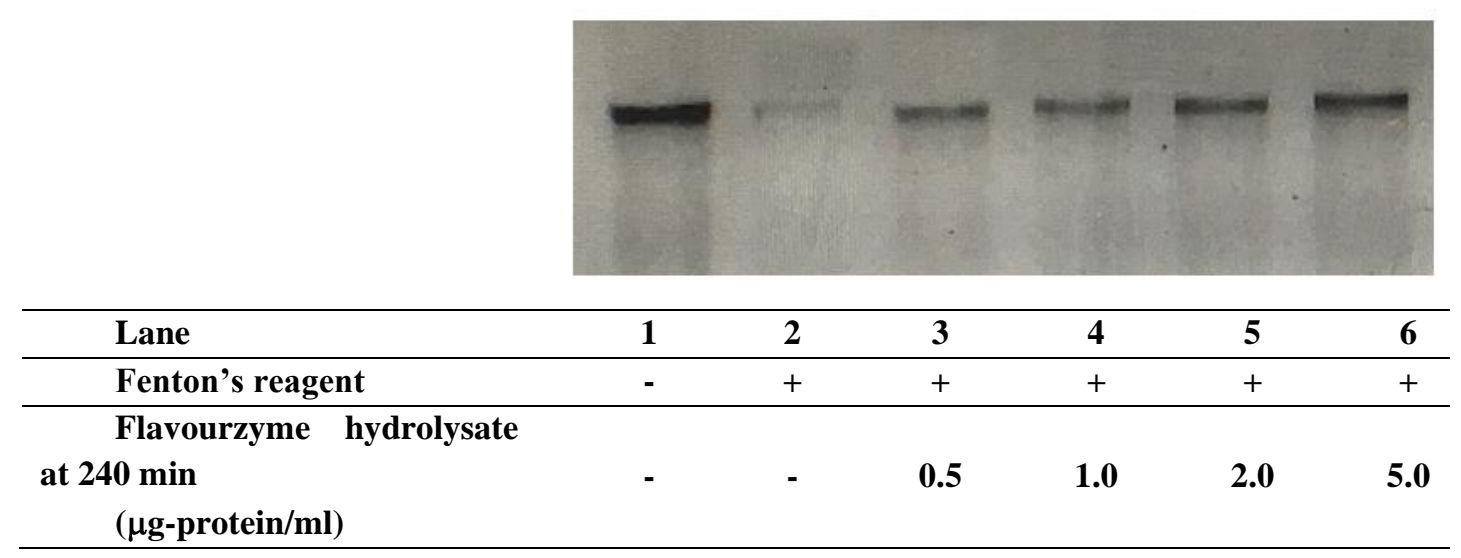

Figure 4. Agarose gel electrophoretic analysis of oxidative DNA damage induced by the Fenton's reaction on a genomic DNA in the presence and absence of 240-min Flavourzyme ${ }^{\circledR}$ hydrolysates. Lane 1, DNA control; Lane 2, DNA with Fenton's reagent; Lanes 3-6, DNA with Fenton's reagent and a hydrolysate sample at concentration of $0.5,1.0,2.0$ and $5.0 \mu \mathrm{g}$-protein $/ \mathrm{ml}$ respectively.

RJ hydrolysate could protect DNA through scavenging the hydroxyl radicals by donating a hydrogen atom or electron. It has previously been proposed that RJ might exert beneficial effects through its antioxidant activity and play a central protective role against ROS-induced tissue damage [45]. It has also been shown that the unsaturated fatty acids (trans-10-hydroxy-2-decenoic acid and 10-hydroxydecenoic acid) from RJ contributed to its in vitro antioxidant effects. Therefore, it could be concluded that the antioxidant activities of hydrolyzed RJ could be related to the unsaturated fatty acids, phenolic compounds, and bioactive peptides containing hydrophobic and aromatic amino acids [46-47].

\section{Anti-allergic activity}

Rat basophilic leukemia (RBL-2H3) cells are mucosal mast cells that have been used often for studying anti-allergic property in diverse areas of functional foods and medicines. Betahexsosaminidase $(\beta$-HEX) is stored in the secretory granules of RBL-2H3 cells and released along with histamine when the cells are immunologically activated. Hence, this enzyme is commonly used as a degranulation marker of mast cells and can reflect changes in other inflammatory factors [19]. For cell viability evaluation with MTT assay, RBL-2H3 cells were exposed to various concentrations of hydrolyzed RJ (0-10 mg-protein/ml). These hydrolysates showed minimal toxicity on RBL-2H3 cells as the percentages of cell viability were all over $80 \%$ (data not shown) [26]. Hence, RJ hydrolysates at those concentrations are safe for assessing anti-allergic activity in RBL-2H3 mast cells.

To assess the ability of RJ and hydrolyzed RJ to inhibit degranulation, RBL-2H3 cells were primed with anti-DNP IgE antibody and then treated with RJ or RJ hydrolysates, followed by stimulation with DNP-BSA and measurement of $\beta$-HEX release. The results showed that the $\mathrm{IC}_{50}$ values of hydrolyzed RJ were lower than non-hydrolyzed one for all proteases (Figure 5). This result was similar to previous works in which the enzymatic hydrolysis improved the biological properties of food proteins by production of the bioactive peptides that were encrypted within the parent proteins $[33,35,38$, and 42$]$. In addition, the $\mathrm{IC}_{50}$ of all hydrolyzed samples significantly 
decreased $(\mathrm{p}<0.05)$ with increasing hydrolysis time, while DH showed an increase with the progression of hydrolysis. This decrease in $\mathrm{IC}_{50}$ was steep up to $240 \mathrm{~min}$ and then became more slowly thereafter (Figure 5). The strongest anti-allergic effect was found for 240-min Flavourzyme ${ }^{\circledR}$ hydrolyzed $\mathrm{RJ}$ with the $\mathrm{IC}_{50}$ of $0.19 \pm 0.01 \mathrm{mg}$-protein $/ \mathrm{ml}$ (Figure $5 \mathrm{~B}$ ). These results together indicated that the inhibitory activities of RJ hydrolysates can be affected by protease type and hydrolysis time.

The ability of RJ hydrolysates to inhibit $\beta$-HEX release might be due to hydrophobic and hydrophilic amino acid residues in the hydrolysates. Peptides with high contents of hydrophobic or hydrophilic amino acids may easily bind to the $\varepsilon$ heavy chains of $\operatorname{IgE}$ at the antigen binding sites, causing the blockade of IgE binding to FceRI on mast cells [48]. Subsequently, this would lead to a reduction in $\beta$-HEX release. Amino acid compositions and peptide sequences also play important roles in anti-allergic activity. Several reports showed that peptides obtained from various sources of protein hydrolysates with different sizes, residues and sequences affected the antiallergic activity, such as the hydrolysates from egg white, soybean, or synthetic peptides [49-50]. Moreover, the physiochemical structures of peptides are also an important factor for the antiallergic activity. It has been shown that peptides with a high content of $\alpha$-helical conformation at their C-terminus could enhance inhibition of both $\beta$-HEX release and IgE-receptor interaction. Thus, our finding was in agreement with these previous studies regarding the possible anti-allergic roles of RJ-derived peptides.
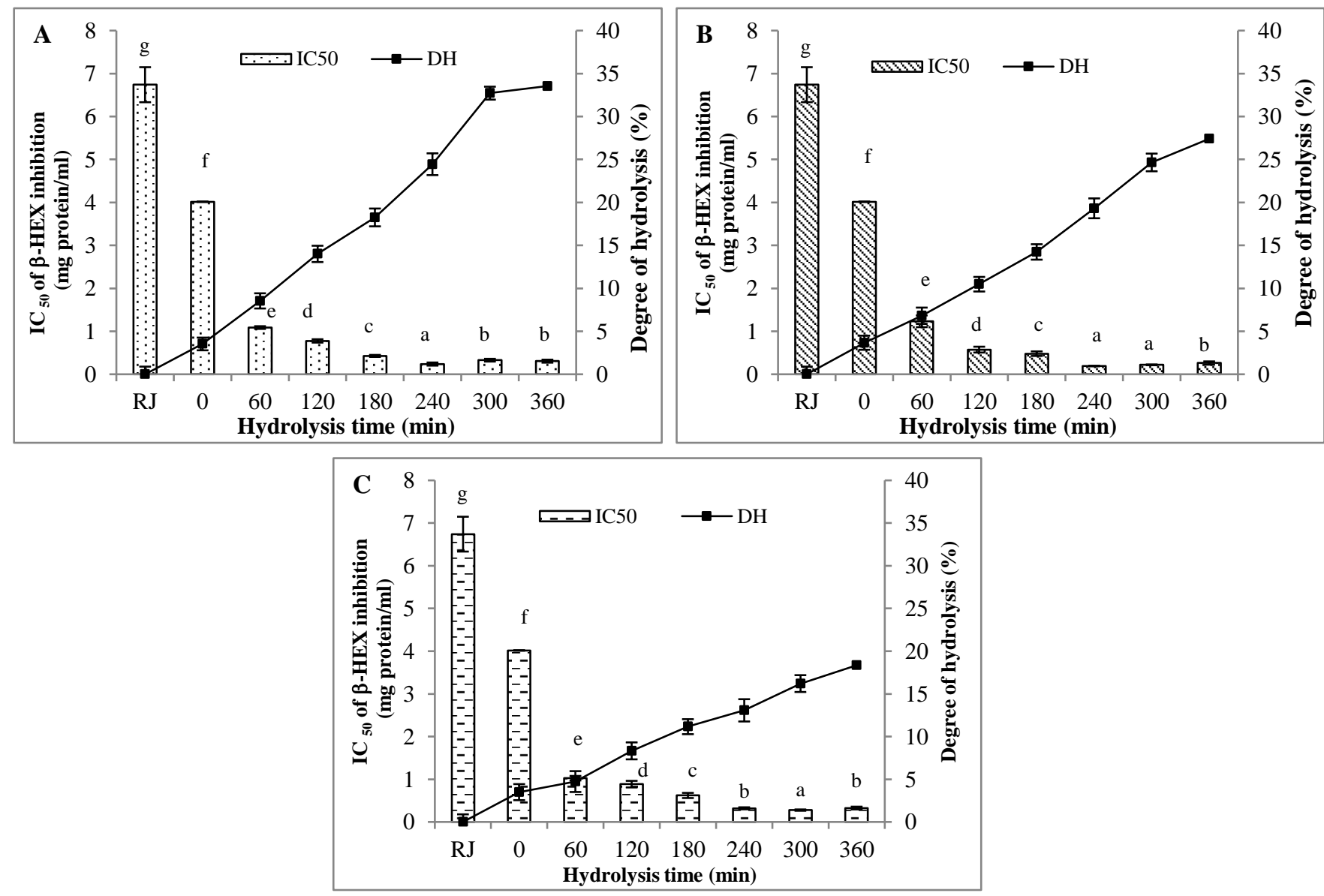

Figure 5 Hydrolysis-time dependent inhibition of $\beta$-HEX secretion by hydrolyzed RJ using (A) Alcalase ${ }^{\circledR}$, (B) Flavourzyme ${ }^{\circledR}$, and (C) Protamex ${ }^{\circledR}$. IC50 was overlaid with degree of hydrolysis (DH). Letters depicted statistically significant differences at $\mathrm{p}<0.05$. 


\section{CONCLUSION}

Royal jelly hydrolysates derived by hydrolysis using three commercial proteases (Alcalase ${ }^{\circledR}$, Flavourzyme ${ }^{\circledR}$, and Protamex $\left.{ }^{\circledR}\right)$ all possessed anti-inflammatory and anti-allergic effects without affecting the viability of macrophages and mast cells. Our results indicated that their ability to suppress NO production and $\beta$-HEX release could be affected by protease type and hydrolysis time. Flavourzyme ${ }^{\circledR}$ hydrolysates exhibited the greatest activity for both properties; the lowest $\mathrm{IC}_{50}$ for NO production and $\beta$-HEX release inhibition was observed at $240 \mathrm{~min}$ with the value of $0.15 \pm 0.03$ and $0.19 \pm 0.01 \mathrm{mg}$-protein $/ \mathrm{ml}$, respectively. The anti-inflammatory effect could be linked to their anti-oxidative property and DNA damage protective activity. The inhibition of $\beta$ HEX release might be due to a membrane-stabilizing action or/and blockade of IgE-receptor interaction. Taken together, these results suggested that RJ hydrolysates could be further developed into functional foods and ingredients for anti-inflammatory and anti-allergic purposes.

List of Abbreviations: RJ, royal jelly; NO, nitric oxide; iNOS, inducible NO synthase; PAF, platelet aggregating factor; $\beta$-HEX, $\beta$-hexosaminadase; MEM, minimum essential medium eagle; IgE, immunoglobulin E; LPS, lipopolyscacharide; MTT, 3-(4,5-dimethyl-2-thiazolyl)-2,5diphenyl-2H-tetrazolium bromide; TNF- $\alpha$, tumor necrosis factor- $\alpha$; IL-6, interleukin 6; IL-10; Interleukin 10; IL-12, Interleukin 12; IFN- $\gamma$, interferon gamma; 1-NA, 1-nitroarginine; FCS, fetal calf serum; ATCC, American Type Culture Collection; BSA, bovine serum albumin; DH, degree of hydrolysis; TNBS, trinitobenzene sulfonic acid; ROS, reactive oxygen species; DNA, deoxyibonucleic acid.

Competing Interests: There are no conflicts of interest to declare.

Author's Contributions: Worrapanit Chansuwan and Nualpun Sirinupong designed, analyzed data and contributed fundamental conceptualization for the research; Worrapanit Chansuwan is the main investigator for this study, wrote the manuscript as well as performed the experiment; Matthawan Khamhae performed the experiment in part of DNA damage protection. Nualpun Sirinupong and Zhe Yang critically revised the manuscript. All authors read and approved the final version of the manuscript.

Acknowledgements and Funding: This work was financially supported from Government Budget Grant (PHY610130S), Prince of Songkla University, Hat Yai, Songkhla, Thailand.

\section{REFERENCES}

1. Hilliam H: Functional food: How big is the market? World Food Ingredients 2000, 12: 50-53.

2. Henry C: Functional foods. Eur J Clin Nutr 2010, 64: 657-659, doi:10.1038/ejen.2010.101

3. Ramadan MF, Al-Ghamdi A: Bioactive compounds and health-promoting properties of royal jelly: a review. J Funct Foods 2012, 4(1): 39-52. 
4. Mozafar K, Atefe A, Elham G: New Findings on Biological Actions and Clinical Applications of Royal Jelly: A Review, J Diet Suppl 2017, DOI: 10.1080/19390211. 2017. 1363843

5. Kunugi, H, Mohammed AA: Royal Jelly and Its Components Promote Healthy Aging and Longevity: From Animal Models to Humans. Int J Mol Sci 2019, 20(19): 4662. doi:10.3390/ijms 20194662.

6. Kocot J, Kielczykowska M, Luchowska-Kocot D, Kurzepa J, Musik I: Antioxidant Potential of Propolis, Bee Pollen, and Royal Jelly: Possible Medical Application. Oxid. Med. Cell Longev 2018, 2018:7074209. doi: 10.1155/2018/7074209.

7. Ahmad S, Campos MG, Fratini F, Altaye SZ, Li J: New Insights into the Biological and Pharmaceutical Properties of Royal Jelly. Int J Mol Sci 2020, 21(2): 382.

8. Khazaei M, Ansarian A, Ghanbari E: New Findings on Biological Actions and Clinical Applications of Royal Jelly: A Review J Diet Suppl 2018, 15(5): 757-775.

9. Viuda-Martos M, Pérez-Alvarez JA, Fernández-López J: Royal Jelly: Health Benefits and Uses in Medicine. Bee Products - Chemical and Biological Properties 2017: 199218. ISBN: 978-331959689-1; 978-331959688-4. doi: 10.1007/978-3-319-59689-1_10.

10. Chen YF, Wang K, Zhang YZ, Zheng YF, Hu FL: In vitro anti-inflammatory effects of three fatty acids from royal jelly. Mediat Inflamm 2016, Article ID 3583684. doi: 10.1155/2016/3583684

11. Anna GS, Gian LM, Maria FC, Stefan B, Ligia BAM: Quality and standardization of Royal Jelly, Journal of ApiProduct and ApiMedical Science 2009, 1(1): 1-6.

12. Bellik Y, Boukraâ L, Alzahrani HA, Bakhotmah BA, Abdellah F, Hammoudi SM, IguerOuada M: Molecular mechanism underlying anti-inflammatory and anti-allergic activities of phytochemicals: an update. Molecules (Basel, Switzerland 2012, 18(1): 322-353. doi: 10.3390/molecules18010322.

13. Alessandri AL, Sousa LP, Lucas CD, Rossi AG, Pinho V,Teixeira MM: Resolution of inflammation: mechanisms and opportunity for drug development. Pharmacol. Ther 2013, 139: 189-212. doi: 10.1016/j.pharmthera.2013.04.006

14. Libby P: Inflammatory mechanisms: the molecular basis of inflammation and disease. Nutr Rev 2007, 65: S140-S146.

15. Chen L, Deng H, Cui H, Fang J, Zuo Z, Deng J, Li Y, Wang X, Zhao L: Inflammatory responses and inflammation-associated diseases in organs. Oncotarget 2018, 9:72047218. doi:10.18632/oncotarget.23208.

16. Bellik Y, Boukraa L, Alzahrani HA, Bakhotmah BA, Abdellah F, Hammoudi SM, IguerOuada M: Molecular Mechanism Underlying Anti-Inflammatory and Anti-Allergic Activities of Phytochemicals: An Update. Molecules 2012, 18: 322-353.

17. Surh YJ, Chun KS, Cha HH, Han SS, Keum YS, Park KK, and Lee SS: Molecular mechanisms underlying chemopreventive activities of anti-inflammatory phytochemicals: Down-regulation of COX-2 and iNOS through suppression of NF- $\kappa \mathrm{B}$ activation. Mut. Res 2001, 480: 243- 268.

18. Brito FA, Lima LA, Ramos MFS, Nakamura MJ, Cavalher-Machado, SC, Siani AC, Henriques MGMO, Sampaio ALF: Pharmacological study of anti-allergic activity of Syzygium cumini (L.) Skeels. Braz. J. Med. Biol. Res. 2007, 40: 105-115. 
19. Matsuda H, Sugimoto S, Morikawa T, Mutsuhira K, Mizuguchi E, Nakamura S, Yoshikawa S: Bioactive constituent from chinese natural medicines: Inhibitors of antigeninduced degranulation in RBL-2H3 Cells from the seeds of Psoralea corylifolia. Chem Pharm Bull 2007, 55 (1): 106 - 110.

20. Leung R, Thien FCK, Baldo B, Czarny D: Royal jelly-induced asthma and anaphylaxis: Clinical characteristics and immunological correlations. Journal Allergy Asthma and Immunology 1997, 96: 1004-1007.

21. Lombardi C, Senna GE, Gatti B, Feligioni M, Riva G, Bonadonna P, Damma AR, Canonica GW, Passalacqua G: Allergic reactions to honey and royal jelly and their relationship with sensitization to composite. Allergol Immunopathol 1998, 26(6): 288290.

22. Takahama H, Shimazu T: Food-induced anaphylaxis caused by ingestion of royal jelly. J Dermatol 2006, 33: 424-426.

23. Yoko M, Yoshinao S, Toshiya T, Takahiko T, Tatsuya M, Mariko S: 2011. Major royal jelly protein 3 as a possible allergen in royal jelly-induced anaphylaxis. J Dermatol 2011, 38: 1079-1081.

24. Kim JM, Han SM, Cho ML, Lee KG, Lee ML, Lee MY, Woo SO, Hong IP, Sim HS, Choi YS: Characterization of Water Soluble Royal Jelly Removed Allergenic protein. J Apic 2013, 28: 19-23.

25. Yoon JM, Kang HJ, Choi ES, Moon MS, Kim KS, Kim YH: Development of Preparation Method of Enzyme-Treated Royal Jelly. J Apic 2014, 29: 161-166.

26. Chansuwan W., Takahashi Upunqui C. Chinachoti P: Anti-inflammatory and anti-allergic activities of Skipjack tuna (Katsuwonus pelamis) dark muscle hydrolysates evaluated in cell culture model. Functional Foods in Health and Disease 2019; 9(7): 446-465.

27. Kim YS, Young MR, Bobe G, Colburn NH, Milner JA: Bioactive food components, inflammatory targets, and cancer prevention. Cancer Prev Res 2009, 2: 200-208.

28. Lowry OH, Rosebrough NJ, Farr AL, Randall RJ: Protein measurement with the Folin phenol reagent. J Biol Chem 1951, 193:264-275.

29. Adler-Nissen, J: Determination of degree of hydrolysis of food protein hydrolysates by trinitrobenzenesulfonic acid. J Agr Food Chem 1979, 27(6): 1256-1262.

30. Laemmli UK: Cleavage of structural proteins during the assembly of the head of bacteriophage T4. Nature. 1970, 227:680-685. doi: 10.1038/227680a0.

31. Schägger H, Von Jagow GV: Tricine sodium dodecyl sulfate-polyacrylamide gel electrophoresis for the separation of proteins in the range from 1 to $100 \mathrm{kDa}$. Anal. Biochem. 1987, 166: 368-379.

32. Jiang Y, Han W, Shen T, Wang MH: Antioxidant activity and protection from DNA damage by water extract from pine (Pinus densiflora) bark. Preventive nutrition and food science 2012, 17(2): 116.

33. Bita F, Afshin E, Jamilah B, Azizah AH, Zaiton H, Nazamid S: Enzyme Hydrolysates from Stichopus horrens as a New Source for Angiotensin-Converting Enzyme Inhibitory Peptides. Evidence-Based Complementary and Alternative Medicine Article 2012, ID 236384, 9 pages doi:10.1155/2012/236384. 
34. Pedroche J, Yust MM, Girón-Calle J, Alaiz M, Millán F, Vioque J: Utilisation of chickpea protein isolate for production of peptides with angiotensin I-converting enzyme (ACE)inhibitory activity. J Sci Food Agri 2002, 82(9): 960-965.

35. Vaštag Ž, Popović L, Popović S, Krimer V, Peričin D: Production of enzymatic hydrolysates with antioxidant and angiotensin-I converting enzyme inhibitory activity from pumpkin oil cake protein isolate. Food Chem 2011, 124(4): 1316-1321.

36. Beutler B: Innate immunity: an overview. Mol Immunol 2004, 40: 845-859.

37. Chang YC, Li PC, Chen BC, Chang MS, Wang JL, Chiu WT, and Lin CH: Lipoteichoic acid-induced nitric oxide synthase expression in RAW264.7 macrophages is mediated by cyclooxygenase-2, prostaglandin E2, protein kinase A, p38 MAPK, and nuclear factor-кB pathways. Cell Signal 2006, 18: 1235-1243.

38. Ahn CB, Cho YS, Je JY: Purification and anti-inflammatory action of tripeptide from salmon pectoral fin byproduct protein hydrolysate. Food Chem 2015, 168: 151-156.

39. Hwang JS, Yoo HJ, Song HJ, Kim KK, Chun YJ, Matsui T, and Kim HB: Inflammationrelated signaling pathways implicating TGF $\beta$ are revealed in the expression profiling of MCF7 cell treated with fermented soybean, chungkookjang. Nutr Cancer. 2011, 63(4): 645-52. 10.1080/01635581.2011.551987

40. 40 Majumder K, Chakrabarti S, Davidge ST, Wu J: Structure and activity study of egg protein ovotransferrin derived peptides (IRW and IQW) on endothelial inflammatory response and oxidative stress. J Agr Food Chem. 2013, 61(9): 2120-9. 10.1021/jf3046076

41. Iskandar MM, Dauletbaev N, Kubow S, Mawji N, and Lands LC: Whey protein hydrolysates decrease IL-8 secretion in lipopolysaccharide (LPS)-stimulated respiratory epithelial cells by affecting LPS binding to Toll-like receptor 4. Br J Nutr. 2013, 110(1): 58-68. 10.1017/S000 7114512004655.

42. Hyejung G, In-Bong S, Hye-Ju H, Na-Young L, Ji-Yun C, Yeon-Kyong S, Jungkee K. Anti-inflammatory and immune-enhancing effects of enzyme-treated royal jelly. Appl Biol Chem 2018, 61(2): 227-233. https://doi.org/10.1007/s13765-018-0349-5.

43. Inkanuwat A, Sukaboon R, Reamtong O, Asawanonda P, Pattaratanakun A, Saisavoey T, Sangtanoo P, Karnchanatat A: Nitric oxide synthesis inhibition and anti-Inflammatory effect of polypeptide isolated from chicken feather meal in lipopolysaccharide-stimulated RAW 264.7 Macrophages. Food Technol Biotechnol 2019, Jun; 57(2): 200-212. doi: 10.17113/ftb.57.02.19.5964. PMID: 31537969; PMCID: PMC6718961.

44. Limmongkon A, Pankam J, Somboon T, Wongshaya P, Nopprang P: Evaluation of the DNA damage protective activity of the germinated peanut (Arachis hypogaea) in relation to antioxidant and anti-inflammatory activity. LWT 2019, 101: 259-268.

45. Ghanbari E, Nejati V, Khazaei M: Antioxidant and protective effects of Royal jelly on histopathological changes in testis of diabetic rats. Int J Reprod Biomed (Yazd) 2016, 14: 519-526.

46. Maqsoudlou A, Sadeghi MA, Mora L, Mohebodini H, Toldrá F, Ghorbani M: Peptide identification in alcalase hydrolysated pollen and comparison of its bioactivity with royal jelly. Food Res Int 2018, 116: 905-915. DOI: 10.1016/j. foodres.2018.09.027.

47. Yi-Fan C, Kai W, Yan-Zheng Z, Yu-Fei Z, Fu-Liang H: In Vitro Anti-Inflammatory Effects of Three Fatty Acids from Royal Jelly. Mediators Inflamm 2016, Article ID 3583684, 11 pages. http://dx.doi.org/10.1155/2016/3583684. 
48. Buku A, Keselman I, Lupyan D, Mezei M, Price JA: Effective mast cell degranulating peptide inhibitors of the IgE/FceRIreceptor interaction. Chem Biol Drug Des 2008, 72(2): 133-139. https://doi.org/10.1111/j.1747-0285.2008.00684.x

49. Buku A, Condie BA, Price JA, Mezei M: [Ala12] MCD peptide: A lead peptide to inhibitors of immunoglobulin E binding to mast cell receptors. Chem Biol Drug Des 2005, 66(3): 132-137. https://doi.org/10.1111/j.1399-3011.2005.00281.x.

50. Kim K, Kim Y, Kim HY, Ro JY, Jeoung D: Inhibitory mechanism of antiallergic peptides in RBL2H3 cells. Eur J Pharmacol 2008, 581(1-2): 191-203. https://doi.org/10.1016/j.ejphar. 2007.11.033.

51. You MM, Chen YF, Pan YM, Liu YC, Tu J, Wang K, Hu FL: Royal Jelly Attenuates LPSInduced Inflammation in BV-2 Microglial Cells through Modulating NF- $\kappa$ B and p38/JNK $\begin{array}{llll}\text { Signaling } \quad \text { Pathways. Mediators inflamm } & \text { 2018, }\end{array}$ https://doi:10.1155/2018/7834381.

52. Rosmilah M, Shahnaz M, Patel G, Lock J, Rahman D, Masita A, Noormalin A: Characterization of major allergens of royal jelly Apis mellifera. Trop. Biomed 2008, $25 ; 243-251$.

53. Takeshi H, Nobue $T$, Takashi N, Takashi A: Immunological Characterization of Honey Proteins and Identification of MRJP 1 as an IgE-Binding Protein. Biosci Biotechnol Biochem 2011, 75(3); 556-560, https://DOI: 10.1271/bbb.100778. 